\title{
LABORATORY EVALUATION OF FOUR STRAINS OF PATHOGENIC NEMATODE SPECIES ON MAJOR INSECT PESTS OF SUGAR BEET.
}

Hussein, S.H.A.; El-Sappagh, I.A. and Azazy, A.M. Plant protection Res. Institute - Dokki, Agricultural Res. center

\section{ABSTRACT}

Evaluation of the entomopathogenic nematodes species, Steinrnmema rarum, Steinrnmema carpocapsae (Sc), Steinrnmema spp (S6) and Heterorhabditis spp (HLs) against the prepupae and pupae of Pegomya mixta, larvae and pupae of Lixus junci and Hymenia recurvalis was carried out at $25^{\circ} \mathrm{C}$ and $65 \%$ R.H.

Concentration 500 and $250 \mathrm{IJs} / \mathrm{ml}$ were tested and the results indicated that the mortality rate increased with increased dosage of nematodes. The highest mortality was $62.5 \%$ for $(S 6)$ and $(S c)$ against prepual stage of $P$. mixta at $250 \mathrm{IJs} / \mathrm{ml}$, while it was moderate mortality was for $S$. rarum and HLs. The highest mortality of $S$. rarum was against pupal stage for some concentrations and other treatments gave moderate mortality, compared with the control. Also, the mortality percentages were the same for all treatments against prepupal and pupal stages at $500 \mathrm{IJ} / \mathrm{ml}$, except for (S6) treatment with $92.5 \%$ mortality at the same concentration.

All nematode species tested gave complete mortality (100\%) for $L$. junci larvae when applied at either 500 or $250 \mathrm{IJ} / \mathrm{ml}$.

Key words: Laboratory studies; Pathogenic nematode; Insedt pests and Sugar beet.

\section{INTRODUCTION}

Sugar beet is an important crop for sugar production, providing approximately a third of all sugar consumed in the world and almost $50 \%$ of U.S. sugar production. In addition, the pulp and molasses of sugar beet are widely used as feed supplements for livestock. This economically important plant is subject to attack by more than 150 species of insects and mites (Harry Lange, 1987). Although conventional pesticide application has been effective for the majority of the pests, many of these toxic chemicals are expensive and may be persistent in the environment

As reported by Guirguis, 1985 and Ali et al. 1993 sugar beet, Beta vulgaris $\mathrm{L}$. is one attractive crop to many pests such as Hymenia recurvalis, Pegomya mixta and Lixus junci Boh, due to its prolonged growing season. These pests are responsible for reducing sugar production. Guirguis in Egypt.

Therefore, it was necessary to apply biological pest management using entomopathogenic nematodes that have been registered to be ecologicaly safe and risk free (Bedding et al., 1996 and El-Deeb et al., 2004). A large complex of insect pests are found in sugar beet ecosystem whatever the crop is grown. The Hawaiian beet web worm, Hymenia recurvalis, (Fab.), the beet fly, Pegomya mixta and the beet weevil, Lixus junci Boh. are the most important insect pests at Fayoum Governorate (Hussien, 2001 and 2005).

The present study was carried out to evaluate effect of entomopathogenic nematodes against the above mentioned insects. These nematodes are $S 6$, $S s, S$. ratum and HLs.

Fayoum J. Agric. Res. \& Dev., Vol. 26, No.2, July, 2012 


\section{MATERIALS AND METHODS}

Three Steinernematids and one Heterorhabditis entomopathogenic nematode strains were obtained from the Insect Physiology Lab., Plant Protection Research Institute, Dokki, Egypt. Steinrnmema rarum, S. carpocapsae (Sc) (original from Florida, USA), and Steinrnmema spp (S6) and Heterorhabditis spp (HLs) isolated from soil taken from EL-Kasaseen ,Ismailia Governorate. The nematodes were reproduced in vivo on larvae of the wax worm Galleria mellonella L. and maintained in the laboratory using the method of Woodring and Kaya, 1988. These nematodes were tested against three sugar beet pests as follows:

\section{1-Pegomya mixta:-}

Larva were collected from field infestation of sugar beet plants at ELHadkh village, Fayoum Governorate, Egypt. These larvae were placed in plastic cups (10 larvae /cup) on $20 \mathrm{gm}$ of moistened sterilizer soil and transferred to the laboratory.

New larval stage of $P$. mixta were treated with nematodes (Sc. S6, S. rarum and HLs at two concentrations (i.e. 250 and $500 \mathrm{IJs} \mathrm{ml}$ ). Treatments were replicated four times and mortality of the pre-pupa and pupa were calculated after four days.

\section{2- Lixus junci:}

These larvae were collected from the necks of infested leaves of sugar beet plants, transferred to the lab., and subjected to two concentrations (500 and $250 \mathrm{IJs} / \mathrm{ml}$ ) of the chosen nematodes. Mortality of larvae and pupae were calculated after four days of treatments.

\section{3- Hymenia recurvalis:}

Seedlings of sugar beet were transported in plastic cups to the lab. Artificial infestation using five larvae $\left(4^{\text {th }}\right.$ instar) on each seedling. Each treatment was replicated four times. Seedlings were sprayed by two nematode strains, i.e. Sc and S. rarum, at two concentrations 500 and $250 \mathrm{IJs} / \mathrm{ml}$ by a handle machine gun. The mortality percentages were calculated by Abbott formula, 1925.

\section{RESULTS AND DISCUSSION \\ 1- The effect of $S C, S 6$, HLs and $S$. rarum on pre-pupal and pupal stages of Pegomia mixta: \\ The results presented in Table (1) and Fig.(1\& 2) revealed that all the} nematodes tested were effective on pre-pupal and pupal stages at two concentrations (500 and $250 \mathrm{IJs} / \mathrm{ml}$ ). The nematode Sc and S6 strains were more effective on prepupa at $250 \mathrm{IJ} / \mathrm{ml}$ concentration $62.5 \%$ mortality, while, the same strains were less effective on the pupal stage showing 35 and $37.5 \%$ mortality for strain, respectively. The nematode $S$. rarum was more effective, however, with $65 \%$ mortality at the same concentration.

On the other hand, all tested nematodes gave higher mortalities of prepupae and pupae at $250 \mathrm{IJs} / \mathrm{ml}$ concentration. The results showed that S6 strain was more effective against prepupae at concentration $500 \mathrm{IJ} / \mathrm{ml}$, with $9205 \%$ mortality against the two stages of this insect.

These results suggest that most of the nematode species can be used for controlling $P$. mixta when used at $500 \mathrm{IJs} / \mathrm{ml}$ concentration.

Fayoum J. Agric. Res. \& Dev., Vol. 26, No.2, July, 2012 
LABORATORY EVALUATION OF FOUR STRAINS OF ...

Table (1): Mortality of prepupal and pupal stages of $P$. mixta treated with four nematode strains

\begin{tabular}{|c|c|c|c|c|c|c|c|c|c|}
\hline \multirow{4}{*}{$\begin{array}{l}\text { Nematode } \\
\text { species }\end{array}$} & \multicolumn{9}{|c|}{ Concentrations } \\
\hline & \multicolumn{4}{|c|}{$250 \mathrm{IJs} / \mathrm{ml}$} & \multicolumn{5}{|c|}{$500 \mathrm{IJs} / \mathrm{ml}$} \\
\hline & \multicolumn{2}{|c|}{ PrepupalStage } & \multicolumn{2}{|c|}{\begin{tabular}{|l|} 
Pupal stage \\
\end{tabular}} & \multicolumn{2}{|c|}{ Prepupal Stage } & \multicolumn{3}{|c|}{ Pupal stage } \\
\hline & Dead & $\begin{array}{c}\% \\
\text { Mortality }\end{array}$ & Dead & $\begin{array}{c}\% \\
\text { Mortality }\end{array}$ & Dead & $\begin{array}{c}\% \\
\text { Mortality }\end{array}$ & alive & Dead & $\begin{array}{c}\% \\
\text { Mortality }\end{array}$ \\
\hline $\mathrm{SC}$ & 25 & 62.5 & 14 & 35 & 17 & 67.5 & 27 & 13 & 32.5 \\
\hline S6 & 25 & 62.5 & 15 & 37.5 & 37 & 92.5 & 37 & 3 & 7.5 \\
\hline HLs & 18 & 45 & 22 & 55 & 16 & 40 & 16 & 24 & 60 \\
\hline S. rarum & 12 & 30 & 26 & 65 & 14 & 35 & 14 & 26 & 65 \\
\hline Control & 3 & 7.5 & 2 & 5.0 & 3 & 7.5 & 38 & 2 & 5.0 \\
\hline
\end{tabular}

- Nuber of tested larvae $=40 /$ treatment.

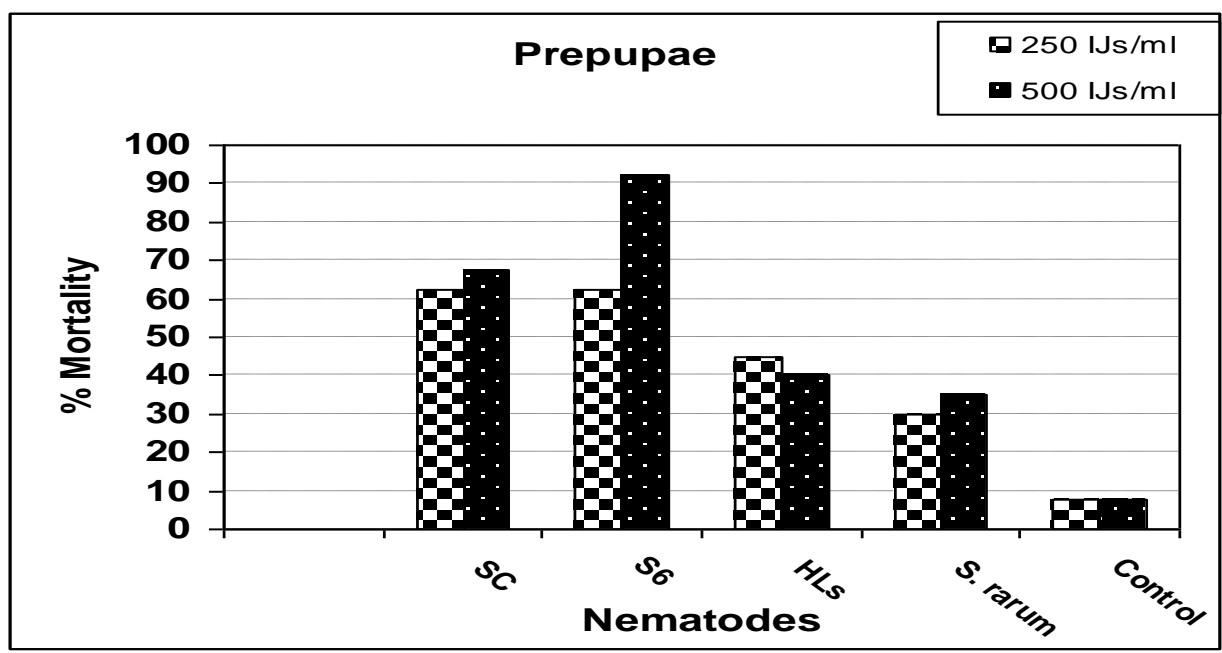

Fig.(1): Effect of different concentrations of entomopathogenic nematode strains on pre-pupal stage of Pegomya mixta.

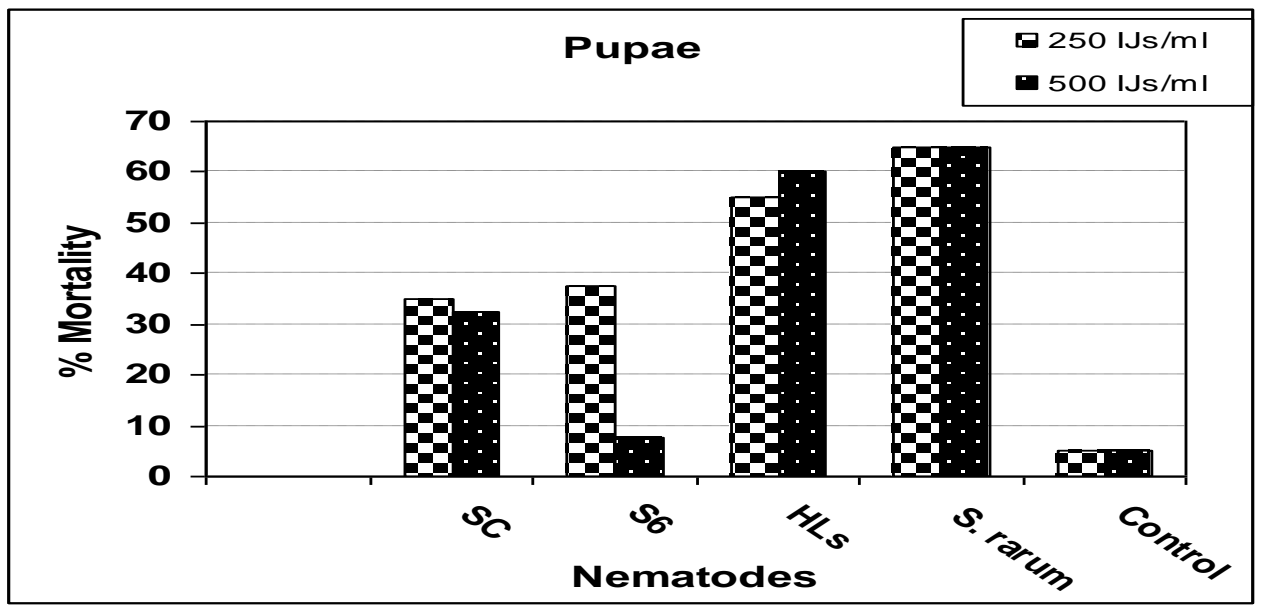

Fig.(2): Effect of different concentrations of entomopathogenic nematode strains on pupal stage of Pegomya mixta.

Fayoum J. Agric. Res. \& Dev., Vol. 26, No.2, July, 2012 
Hussein, S.H.A. et al.,

2- The effect of $S C, S 6$, HLs and $S$. rarum on pre-pupal and pupal stages of Lixus junci:

Data obtained showed that all nematode strains gave complete mortality $100 \%$ for $L$. junci larvae when applied at 500 or $250 \mathrm{IJs} / \mathrm{ml}$ concentrations.

\section{3- The effect of $S C$, S6, HLs and $S$. rarum on pre-pupal and pupal stages} of Hymenia recurvalis:

Data presented in Table (2) and Fig. 3 indicated that the highest percent of reduction for $H$. recurvalis larvae, $18 \%$ and $19 \%$, resulted from using 500 and $250 \mathrm{IJs} / \mathrm{ml}$ concentrations of $S c$, respectively. On the other hand, $S$. rarum strain gave 80 and $60 \%$ mortality at same concentrations, respectively.

The obtained results indicates that the nematodes species chosen can be used for controlling $P$. mixta, $L$. junci and $H$. recurvalis, at concentration not less than $250 \mathrm{IJ} / \mathrm{ml}$.

Generally, the entomopathogenic nematode strains were effective against $L$. junci larvae and $H$. recurvalis under laboratory conditions. The four nematode strains were able to kill larvae of $L$. junci before developing into pupae. This finding is in full accordance with Saleh, 1995, Bader El-Sabah and Azazy, 2004. Similar results were reported by Azazy and Gehad (2005) that the reduction of $H$. undelis was $96.2,94.5$ and $79.5 \%$ for Sr. Hbs1, and Sc., respectively.

Table (2): Effect of direct spray by different nematodes on sugar beet plants infested by Hymenia recurvalis.

\begin{tabular}{|c|c|c|c|c|c|c|}
\hline \multirow{3}{*}{$\begin{array}{c}\text { Concentrations } \\
\text { IJJs/ml }\end{array}$} & \multicolumn{6}{|c|}{ Species } \\
\hline & \multicolumn{3}{|c|}{ SC } & \multicolumn{3}{|c|}{ S. rarum } \\
\hline & Dead & $\begin{array}{c}\% \\
\text { Mortality }\end{array}$ & $\begin{array}{c}\% \\
\text { Reduction }\end{array}$ & dead & $\begin{array}{c}\% \\
\text { Mortality }\end{array}$ & $\begin{array}{c}\% \\
\text { reduction }\end{array}$ \\
\hline 500 & 19 & 95 & 94.7 & 16 & 80 & - \\
\hline 250 & 20 & 100 & 100 & 12 & 60 & - \\
\hline Control & 1.0 & 5 & - & 0.0 & 0.0 & - \\
\hline
\end{tabular}

- Number of larvae $=20$ /treatment

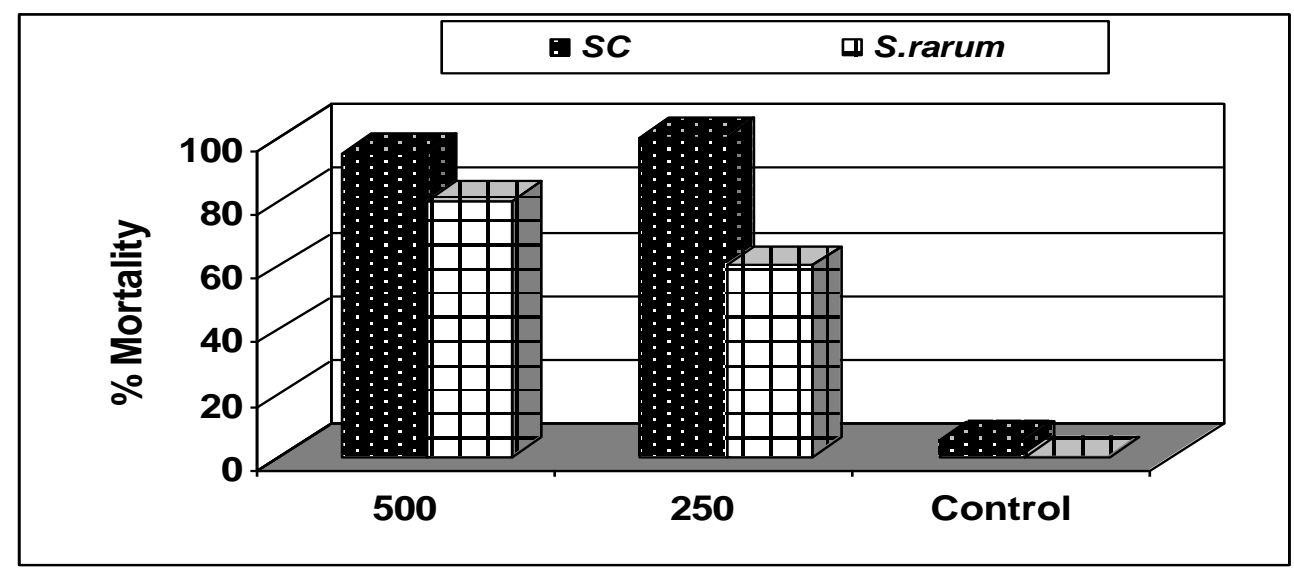

Fig.(3): Effect of different concentrations of nematodes strains on $\boldsymbol{H}$. recurvalis.

Fayoum J. Agric. Res. \& Dev., Vol. 26, No.2, July, 2012 
The results according with Azazy and Gehad, (2005) show that the mortality of $H$. undelis was $96.2,94.5$ and $79.5 \%$ for Sr. Hbs1, and Sc., respectively and was 79.4, 72.2 and $57.7 \%$ for Artogia rapae treated with Hbs1, Sr and Sc, respectively. Also, nematodes have been applied successfully against soil inhabiting insects (as soil application) as well as above-ground insects (foliar spray) in cryptic habitats (Arthers et al., 2004; Shapiro-Ilan et al., 2006). Most nematodes were more virulent to larvae than to pupae. Adults were less susceptible to nematodes than other stages, and adult males were more susceptible than females. Under field conditions $S$. carpocapsae and $H$. bacteriophora reduced weevil densities up to $83 \%$ and $81 \%$ on plants treated with the two species, respectively (Jansson et al., 1990). Richter \& Fuxa (1990) reported 33-43\% infection of $S$. frugiperda by $S$. carpocapsae in corn field. They also found that spraying of nematodes onto corn ears caused up to $71 \%$ infection of $S$. frugiperda and they concluded that $S$. carpocapsae, $S$. riobrave, and $H$. megidis have potential for controlling $S$. frugiperda.

The great advantages of using entomopathogenic nematodes as biopesticides for insect pest control are in operator and end-user safety, absence of withholding periods, the advantage of minimizing the treated area by monitoring insect populations, minimal harm to natural enemies and lack of environmental pollution.

In summary, the present results encourage further studies to evaluate possible integration of potential entomopathogenic nematode species in control programs against the pest insects in the field, especially for sugar beet production.

\section{REFERENCES}

Abbott, W.S. (1925): A method of computing the effectiveness of on insecticides. J. Econ. Entomol. 18; 265-267.

Ali, F.A.;El-Adl, F.E.; Ibrahim, S.M.; Samy, M.A.; El-Khwalka, M.A.; Gaber, A.M.; Adam, K.M. and M.M.A. Mahgoub (1993): Survey and geographical distribution of sugarbeet insect pests in Egypt. J. Agric. Sci. Mansoura Univ., 18 (6): 1937-1804.

Arthurs S.; Heinz KM, Prasifka JR. (2004). An analysis of using entomopathogenic nematodes against above-ground pests. Bull. Entomol. Res. 94, 297-306.

Azazy, A.M. and Gehad, M. Mousa (2006): Biological control of cabbage webworm, Hellula undalis and cabbage worm, Artogia rapaeusing entomopathogenic nematodes on cabbage seedling. Egypt, J. Agric. Res., 33 (2): 457-467.

Bader El-Sabah, A.F. and Azazy, A.M. (2004): Integreated of three biocontrol agents for the control of the cabbage worm, Artogia Pieris rapae (L.). Egyption J. Biolo.Cont. 14 (1): 225-230.

Bedding, R.A.; S. Tyler and N. Rochester (1996): Legislation and the introduction of exotic entomopathogenic nematodes into Asturalia and Newzeland. Biological Science and Technology. 6:465-475.

El-Deeb, A.A.A.; M.A. Azazy; Seham, K. Abdir and M.A. Bekeat (2004): Suppression of the root-knot nematode, Meloidogyne incognita infected tomato plants by entomopathogenic nematodes. Egypt, J. Appl. Sci; 19:705-715.

Harry Lange W. (1987): Insect pests of sugar beet. Ann. Rev. Entomol. $32: 341-60$.

Fayoum J. Agric. Res. \& Dev., Vol. 26, No.2, July, 2012 
Hussein, S.H.A. et al.,

Hussein, S.H.A. (2001): Ecological studies on certain insect pests attaking Sugarbeet crop at Fayoum Governorate. M.Sc. thesis, Faculty of Agric. Fayoum, Cairo Univ. pp 133.

Hussein, S.H.A. (2005): Integrated pest management on Sugar beet at Fayoum Govornorate. Ph.D. thesis, Faculty of Agric. Fayoum, Cairo Univ. pp 105.

Guirguis,G.Z. (1985): Studies on certain insect attacking sugar beet in Westrn Desert, Egypt. Ph.D. Thesis, Faculty of Agric., Menoufya ,Univ.

Jansson R.K.; Lecrone S.H.; Gaugler R. and Smart G.C. (1990): Potential of entomopathogenic nematodes as biological control agents of sweet potato weevil (Coleoptera: Curculionidae). J. Econ. Entomol. 83,18181826.

Saleh. M.M.E. (1995): Efficiency of the Egyption entomopathogenic nematode Heterorhabdities tayseri (Nematoda: Heterorhabditidae) in controlling the cabbage Pieris rapae (L.) (Lepidoptera: Pieridae). Egypt J. Biological pest control, 5(2):103-105.

Shapiro-IIan D.I.; Gough D.H.; Piggott S.J. and Fife J.P. (2006): Application technology and environmental considerations for use of entomopathogenic nematodes in biological control. Biol. Control. $38,124-133$.

Richter A.R. and Fuxa J.R. (1990): Effect of Steinernema feltiae on Spodoptera frugiperda and Heliothis zea (Lepidoptera: Noctuidae) in corn. J. Econ. Entomol.83: 1286-1291.

Woodring, J.L. and Kaya, H.K. (1988): Steinernematid and Heterorabditid Nematodes; A. handbook of biology and techniques southern Cooperation Series Bull.331:30pp.

Fayoum J. Agric. Res. \& Dev., Vol. 26, No.2, July, 2012 